DOl: $10.19195 / 2353-8546.8 .15$

\author{
ANDRZEJ POLAK \\ Uniwersytet Śląski (Katowice, Polska) \\ ORCID: 0000-0002-3665-0115
}

\title{
Kolonizacja wewnętrzna Rosji w ujęciu Aleksandra Etkinda
}

Internal colonization of Russia from the perspective of Alexander Etkind. The article aims to present the most important theses contained in the book of an outstanding Russian postcolonial researcher Alexander Etkind. At the heart of his deliberations lies the assumption that the Russian empire not only dominated foreign territories, but also native territories located in the central governorates of the state. The process was accompanied by colonization of the local population, above all - peasants. Etkind considers the Russian serfdom law and rural community as typical colonial institutions. His interests remain in some writers' attempts to explain the phenomenon of internal colonization. A combination of methods used in historical and literary research results in an interesting interpretation of texts written by Daniel Defoe, Leo Tolstoy, Nikolai Gogol, Joseph Conrad, Immanuel Kant and Mikhail Bakhtin, reflecting their authors' imperial experience. In the article, I focus on the issues included in the introduction and the first two parts of the book.

Keywords: internal colonization, postcolonialism, Russia, border, empire

Celem książki Aleksandra Etkinda - rosyjsko-anglo-amerykańskiego kulturologa i historyka - jest dowiedzenie, że imperium rosyjskie poddawało dominacji zarówno terytoria obce, jak i „rodzime”, niejednokrotnie przyłączone w wyniku wcześniejszych podbojów ${ }^{1}$. Procesowi temu towarzyszyła kolonizacja miejscowej

* Adres do korespondencji: Instytut Filologii Wschodniosłowiańskiej, ul. Grota-Roweckiego 5, 41-205 Sosnowiec. E-mail: andrzejpolakus@op.pl.

1 Problematyce tej poświęcony został tom pod redakcją Aleksandra Etkinda, Dirka Uffelmanna i Ilji Kukulina, zatytułowana Там, внутри. Практики внутренней колонизации в культурной истории России (Новое литературное обозрение, Москва 2012). Pod pojęciem kolonializmu 
ludności - w tym także samych Rosjan, przede wszystkim chłopów. Etkind próbuje ustalić, czy wypracowane na Zachodzie pojęcia kolonizacji i orientalizacji mogą być odnoszone do kultury rosyjskiej. Nie mniejsze znaczenie ma dlań kwestia używania przez historyków rosyjskich terminologii służącej samokolonizacji. Rosyjskie prawo pańszczyźniane oraz wspólnotę wiejską (община) badacz traktuje jako typowe instytucje kolonialne. W kręgu jego zainteresowań pozostają podejmowane przez pisarzy próby wyjaśnienia zjawiska kolonizacji wewnętrznej. Połączenie metod stosowanych w badaniach historycznych i literackich skutkuje nowatorskimi interpretacjami tekstów Daniela Defoe, Lwa Tołstoja, Nikołaja Gogola, Josepha Conrada, Immanuela Kanta i Michaiła Bachtina, odzwierciedlającymi ich doświadczenie imperialne.

Punktem wyjścia refleksji Etkinda są słowa Waltera Benjamina, który podczas pobytu w Moskwie w roku 1927 stwierdził, że Rosjanom obcy jest romantyczny obraz Wschodu $-\mathrm{z}$ ich perspektywy nie zawierał on niczego egzotycznego. Poznani przez Benjamina radzieccy marksiści uznawali „egzotykę" za kontrrewolucyjną ideologię, służącą interesom państw kolonialnych. Bardzo szybko jednak egzotyczny Wschód miał powrócić w nowym radzieckim przebraniu. Moskiewskich intelektualistów zadziwił dystans dzielący ich od chłopów ${ }^{2}$, którzy podczas seansu filmowego nie byli w stanie śledzić dwóch równolegle rozgrywających się wątków fabularnych. Zdecydowana większość z nich potrzebowała nowej sztuki, całkowicie różnej od niezrozumiałej sztuki burżuazyjnej. Jak zauważa Władimir Bobrownikow, w pierwszych dekadach XX wieku ogromna przepaść kulturalna (культурная дистанция) oddzielała potrafiących pisać i czytać członków rosyjskiego społeczeństwa od analfabetów, w szczególności zaś - miasto od wsi ${ }^{3}$. Tego rodzaju różnice kulturowe Etkind uznaje za warunek konieczny „kolonizacji wewnętrznej”. Jak zaznacza: „Нет культурной дистанции - нет колониальной ситуации" ${ }^{\text {. }}$

wewnętrznego autorzy artykułów zamieszczonych w tomie rozumieją odnoszenie praktyk korzystających z władzy i wiedzy, towarzyszących kolonializmowi zewnętrznemu do terytoriów wewnętrznych, grup społecznych i kwestii kulturowych na ogół nie kojarzonych z koloniami. Wedle redaktorów tomu kolonializm wewnętrzny stanowi nie tyle koncepcję, ile metaforę oznaczającą okrutne, nieludzkie traktowanie przez państwo podlegające jego władzy grupy społeczne. Za twórcę terminu „kolonializm wewnętrzny" uznawany jest amerykański badacz Michael Hechter, autor dzieła Internal colonialism. The Celtic fringe in British national development, 1536-1966 (1975). Jak twierdzi Ilja Kukulin, kolonizacja wewnętrzna miała miejsce niemal w każdym państwie. Więcej zob. Россия как колония. Стенограмма обсуждения книги: А. Эткинд, Д. Уффельманн, И. Кукулин, Там, внутри. Практики внутренней колонизации в культурной истории России, Москва 2012. https://polit.ru/article/2013/01/03/ colonization/ (dostęp: 2.11.2018).

2 Jak piszą Etkind, Uffelmann i Kukulin: „Этот народ [chłopi - A.Р.] был своим, он говорил на «нашем» языке и был источником «нашего» благополучия - и при этом всё равно был экзотическим. Россия колонизовала саму себя, осваивала собственный народ. Этот процесс называли внутренней колонизацией, самоколонизацией, вторичной колонизацией собственной территории”. Там, внутри. Практики внутренней..., s. 15.

3 Россия как колония..., s. 9.

${ }^{4}$ Д. Уффельманн, „Подводные камни внутренней (де)колонизации России”, [w:] Там, внутри. Практики внутренней..., s. 61. 
Badacze dziejów imperium rosyjskiego wypracowali dwie przeciwstawne narracje. W pierwszej z nich Rosja prezentowana była jako państwo potężne, skutecznie konkurujące $\mathrm{z}$ innymi europejskimi mocarstwami (w rywalizacji tej istotną funkcję pełniła literatura rosyjska). Druga opowieść kładła z kolei nacisk na zacofanie Rosji, panującą w niej przemoc, nędzę, brak kultury i ogólny upadek. Według Etkinda narracje te tylko pozornie się wykluczają, każda z nich odkrywa bowiem część prawdy. Kluczowe w wywodzie badacza pojęcie kolonizacji wewnętrznej, rozumiane bądź jako metafora, bądź jako mechanizm, pozwala porównać imperium rosyjskie do innych znanych z przeszłości imperiów kolonialnych. W ujęciu Etkinda dwie różne opowieści na temat Rosji współtworzą jedną — historię kolonizacji wewnętrznej, za pomocą której władze imperium dominowały wszystkie zamieszkujące w nim narody.

Jak zauważył w roku 1904 Wasilij Kluczewski, historia Rosji to dzieje państwa dokonującego nieustannej samokolonizacji. Chociaż wektor kolonizacji zwrócony był w głąb kraju, to jej zakres rozszerzał się wraz z przesuwaniem granic w wyniku kolonizacji zewnętrznej. W rosyjskiej myśli społecznej pojęcie samokolonizacji (caмоколонизация) używane było na długo przed Kluczewskim. Rosję opisywano jednocześnie jako podmiot i przedmiot kolonizacji, której towarzyszyła orientalizacja. Państwo rosyjskie podejmowało stałe wysiłki mające na celu kolonizację obszarów wewnętrznych. W odpowiedzi zamieszkujące je narody - w tym sami Rosjanie - zaczęły głosić hasła antyimperialne i nacjonalistyczne. Dwa kierunki rosyjskiej kolonizacji, wewnętrzny i zewnętrzny, albo z sobą konkurowały, albo uzupełniały się wzajemnie. Zdaniem Etkinda wewnętrzne problemy imperium rosyjskiego zbyt rzadko opisywane są z perspektywy postkolonialnej, a takie właśnie ujęcie pozwoliłoby wyjaśnić, dlaczego rewolucja rosyjska i terror radziecki wydarzyły się właśnie w Rosji.

W przekonaniu Etkinda analiza dynamiki kulturowej w jej różnych aspektach wymaga zasypania przepaści dzielącej dwie dyscypliny naukowe - badania historyczne i literackie. $Z$ tego powodu jego książka stworzona została jako interdyscyplinarny projekt badań kulturowych, realizowany z uwzględnieniem perspektywy historycznej. Myśl przewodnią stanowi założenie, wedle którego kultura wysoka - w tym także literatura - odgrywała istotną rolę w rosyjskim procesie politycznym, stając się ważnym aspektem kolonizacji wewnętrznej. Jak przekonywał Michel Foucault, wskutek stosowania przymusu przez władzę kultura staje się politycznie relewantna, władza zaś kulturowo produktywna. Dla osób rządzących imperium rosyjskim kultura była jednocześnie szansą i zagrożeniem. Dzięki niej można było, co prawda, wzmocnić władzę, obawiano się jednak, że będzie ona sprzyjać także rewolucji.

W Rosji rewolucje społeczne powodowały wielkie i tragiczne przemiany, które nie miały jednak poważniejszych konsekwencji dla historycznej, geograficznej i ekologicznej ciągłości imperium. Państwo rosyjskie wkroczyło na światową arenę mniej więcej w tym samym czasie co imperia hiszpańskie i portugalskie. Podbój nowych 
obszarów dokonywał się poprzez rywalizację z imperiami kontynentalnymi - cesarstwem austriackim i Turcją na Zachodzie oraz Chinami i Stanami Zjednoczonymi na Wschodzie. Rosji przyszło także stawić czoła nowożytnym imperiom morskim Wielkiej Brytanii, Francji i Japonii. Ostatecznie imperium rosyjskie okazało się największym i najżywotniejszym spośród imperiów światowych. Chociaż zajmowane przezeń ogromne terytorium powodowało nieustanne perturbacje, to władcy Rosji oraz ich doradcy traktowali bezmiar rosyjskich przestrzeni jako źródło potęgi państwa. Władze zmuszone były tłumić powstania na Uralu i w Polsce, prowadzić wielką grę w Azji Środkowej oraz działania wojenne na Kaukazie. Pomimo tych kłopotów aż do I wojny światowej petersburscy politycy marzyli o przyłączeniu Konstantynopola i Jerozolimy. Dopiero kolejne rewolucje spowodowały zmiany na politycznej mapie Europy oraz w strukturze państwa rosyjskiego. Jednocześnie po rozpadzie Związku Radzieckiego Rosja utraciła mniej terytoriów niż imperia zachodnie w wyniku dekolonizacji.

Goszczący w Rosji w pierwszej połowie XVI wieku austriacki poseł i dyplomata Siegmund von Herberstein zwrócił uwagę na pewną trudność, która do dziś wywołuje spory wśród badaczy. Według niego: „Трудно понять, то ли народ по своей грубости нуждается в государе-тиране, то ли от тирании государя сам народ становится таким грубым, бесчуственным и жестоким" ${ }^{5}$. Na pytanie to całkowicie odmiennej odpowiedzi udzielają mitologia narodowa i nauki polityczne. Zdaniem amerykańskiego dyplomaty George’a Kennana odpowiedzialny za taki stan rzeczy był niepowtarzalny charakter państwowości rosyjskiej oraz cechujące tutejsze władze instynktowne nieustanne poczucie zagrożenia (незащищённость). Winą za „neurotyczną ocenę" własnego położenia Kennan obciążał rządzących. Skutków ich histerycznych obaw doświadczali nie tyle wrogowie zewnętrzni, ile ludność zamieszkująca państwo - zarówno sami Rosjanie, jak i przedstawiciele innych narodowości. Z perspektywy rządzących jedni i drudzy stanowili podobne zagrożenie.

Poczynając od Edwarda Saida, badacze postkolonialni podkreślali znaczenie mórz i oceanów oddzielających metropolie od kolonii, a także samych wypraw morskich. Większość z nich uznawała kolonializm zamorski za bardziej przedsiębiorczy, represyjny i pewniejszy siebie, to jest bardziej imperialistyczny niż kolonializm kontynentalny. $\mathrm{Z}$ różnych powodów w latach pokoju przewóz towarów szlakiem morskim z Archangielska do Londynu okazywał się szybszy i tańszy niż transport lądowy do Moskwy. Przyczyny natury technicznej i psychologicznej powodowały, że droga z Indii do Londynu była krótsza niż z peryferyjnych guberni rosyjskich do stolicy państwa. Morza i oceany łączyły, stały ląd - dzielił. W teorii trajektorie kolonizacji wewnętrznej i zewnętrznej rozmijały się, jednak w praktyce często się krzyżowały, a niekiedy wręcz pokrywały - konkurowały bowiem o dostęp do tych samych zasobów ludzkich, intelektualnych i finansowych.

5 А. Эткинд, Внутренняя колонизация, Москва 2013, s. 13-14. 
Zdaniem Etkinda imperium rosyjskie już u swego zarania pomyślane zostało jako twór kosmopolityczny. Chociaż zaniepokojenie władców Rosji - stale porównujących swoje państwo do innych imperiów europejskich — budziły regiony sprawiające problemy (проблемныье зоны), położone najczęściej na peryferiach państwa, to także Rosjanie etniczni, zamieszkujący gubernie centralne, postrzegani byli jako ograniczony i nie zawsze pewny rezerwuar (pecypc). Wyjątkowy charakter kolonizacji rosyjskiej polegał na stosowaniu kolonialnego systemu władzy niebezpośredniej - przymusowej, wspólnotowej i egzotyzującej - wobec ludności rodzimej. Imperium, dysponujące rozbudowanym aparatem przemocy oraz stosunkowo skromnym kapitałem kulturowym i cywilizacyjnym, zagarniało, a następnie broniło rozległych obszarów przyłączonych do Rosji z powodów, o których po upływie lat pamiętali co najwyżej zawodowi badacze historii.

Etkind zastanawia się, czym tak naprawdę jest kolonizacja wewnętrzna - metaforą czy mechanizmem? Interesuje go, w jaki sposób rosyjska historiografia używała pojęć „,kolonizacja” $i$ „,samokolonizacja” oraz terminów pokrewnych, uwzględniających specyfikę języka rosyjskiego. W odróżnieniu od działaczy państwowych, którzy sporadycznie używali tych pojęć, historycy sięgali po nie dużo częściej. Kolonizacja wewnętrzna jako metafora oddająca istotę mechanizmu sprawowania władzy była w Rosji dobrze znanym i wypróbowanym instrumentem poznania. Na kolonizację zawsze składają się dwa komponenty — kulturowy i polityczny, przy czym oddziaływanie poprzez kulturę sprzyja nie tyle kolonizacji, ile oświeceniu. Badania zjawiska kolonizacji dowodzą, że hegemonia kulturowa i dominacja polityczna występują wspólnie w jednym $\mathrm{z}$ trzech możliwych wariantów - albo się wzajemnie uzupełniają, albo ze sobą konkurują, albo po prostu zachodzą równolegle. Jürgen Habermas opisuje kolonizację wewnętrzną jako metastrukturę (сверхструктура), na kształt której wpływają przemiany natury kognitywnej, prawnej i konstytucyjnej, dokonujące się w obrębie współczesnych społeczeństw.

Zgodnie z powszechnie przyjętą definicją kolonizacja (oraz kolonializm jako wspierający ją system ideologiczny) stanowi akt dominacji, w którego trakcie pewna część ludności przenosi się na terytoria kolonizowane. Pojęcie imperializmu oznacza z kolei bardziej wszechstronną formę dominacji, przy czym migracja nie jest jej warunkiem koniecznym. O ile kolonizacja wymaga transferu mieszkańców poza granice metropolii, o tyle kolonizację wewnętrzną wyróżniają ekspansja kulturowa, hegemonia i asymilacja w obrębie prawdziwych bądź wyobrażonych granic państwa. Kolonizacja, w tym także wewnętrzna, polega na sprawowaniu władzy z uwzględnieniem różnic geograficznych, językowych i kulturowych. Na przełomie XIX i XX stulecia politycy niemieccy realizowali program "kolonizacji wewnętrznej” (Innere Kolonisation) Europy Wschodniej — zakładali bowiem, że ziemie te wchodziły niegdyś w skład państwowości niemieckiej. Historycy rosyjscy (między innymi Afanasij Szczapow, 1830-1876) ukuli z kolei pojęcie „kolonizacji samych siebie” (колонизация себя) - w odróżnieniu od niemieckiej „kolonizacji wewnętrznej” pozbawione 
jednak określonych celów politycznych. Z czasem ukształtował się wokół niego oryginalny, choć zapomniany już dyskurs.

Wskutek rewolucji październikowej oraz dekolonizacji państw Trzeciego Świata koncepcja kolonizacji wewnętrznej na pewien czas straciła na popularności. W roku 1951 Hannah Arendt użyła określenia „bumerang kolonialny” na oznaczenie praktyk pozwalających władzom imperialnym przenosić stosowanie przemocy z kolonii do metropolii. Po roku 1968 socjolodzy zmodyfikowali koncepcję kolonizacji wewnętrznej z zamiarem dostosowania dyskursu postkolonialnego do wewnętrznych problemów metropolii. Robert Blauner, badacz życia czarnoskórych mieszkańców Stanów Zjednoczonych, powstawanie gett oraz starcia na tle rasowym w miastach amerykańskich przedstawił jako skutek kolonizacji wewnętrznej. W połowie lat siedemdziesiątych ubiegłego wieku Michel Foucault posłużył się pojęciem kolonizacji wewnętrznej w szerszym znaczeniu, mając na myśli przenoszenie kolonialnych modeli władzy na Zachód. Koncepcja kolonizacji wewnętrznej zainteresowała ponadto brytyjskiego socjologa Michaela Hechtera, historyka Eugena Webera, socjologa Alvina W. Gouldnera, antropologa Jamesa Scotta, literaturoznawcę Marca Netzloffa oraz środowisko historyków-mediewistów. Choć uznani badacze historii (Fernand Braudel, Hans Rogger, Marc Ferro, Dominic Lieven, Timothy Snyder) zwrócili uwagę na kolonialny charakter polityki wewnętrznej w Rosji, to nie podjęli bardziej szczegółowych analiz tego zjawiska. Rosyjski rozdział historii kolonializmu w badaniach postkolonialnych najczęściej pomijany jest milczeniem. Poza Etkindem spośród znawców literatury rosyjskiej i historii Rosji kolonizacja wewnętrzna interesuje Borisa Grojsa, Borisa Kagarlickiego, Lynne Violę, Nancy Condee, Aleksandra Chramowa, Ilję Kukulina i Dirka Uffelmanna.

Zdaniem Etkinda opracowanie upolitycznionej koncepcji historii kultury wymaga uwzględnienia tradycyjnych metod badawczych stosowanych w literaturoznawstwie, ukierunkowanych na tekst. Zamysł ten ma trzy wymiary - historyczny, kulturowy i polityczny. Etkind podziela stanowisko Ann Laury Stoler, zajmującej się regionem Azji Południowo-Wschodniej, wedle której wymazywanie (исчезновение) kolonializmu (zarówno wewnętrznego, jak i każdego innego) $z$ historii narodów jest zadaniem stricte politycznym. W klasycznej historiografii rosyjskiej, twierdzi Etkind, śladów kolonializmu nigdy nie wymazano całkowicie. $\mathrm{Z}$ tego powodu interesują go polityczne przyczyny obecności lub nieobecności idei wspierających kolonizację zewnętrzną i wewnętrzną w historiografii narodowej (национальная историогра$\oint$ фuя) oraz imperialnej. Zagadnieniom tym poświęcony jest rozdział piąty książki, w którym autor wychodzi poza historię kultury i zwraca się ku ekonomii politycznej w celu lepszego zrozumienia państwowości rosyjskiej w jej długim trwaniu (longue durée). Etkind śledzi współoddziaływanie nieustannie zmieniających się czynników geograficznych, ekologicznych i politycznych oddziałujących na imperialne ambicje Rosji, przy czym jego uwagę skupiają nie tyle wydarzenia historyczne oraz odwieczne praktyki społeczne funkcjonujące w imperium, ile teksty je opisujące. 
Książka Etkinda pomyślana została następująco. W rozdziałach pierwszym i drugim autora interesuje kontekst zimnowojenny Orientalizmu Edwarda Saida, który uzupełniony zostaje o przygody tak zwanych orientalistów w państwie rosyjskim. Kolejna część zawiera przegląd opinii na temat pochodzenia monarchii rosyjskiej oraz istoty kolonizacji wewnętrznej. W rozdziale czwartym badacza zajmuje paradygmat samokolonizacji obecny w pracach historiografów rosyjskich XIX stulecia. W kolejnej części obiektem analizy staje się handel futrami i skórami, dzięki któremu Rosja doświadczyła boomu gospodarczego i dokonała podbojów na Wschodzie. W dwóch kolejnych rozdziałach opisane są dwie charakterystyczne instytucje rosyjskiej kolonizacji wewnętrznej - stany społeczne (сословия) i wspólnota wiejska (община). Postawienie znaku równości między stanem a rasą pozwala Etkindowi zademonstrować, w jaki sposób z forpoczty kolonizacji Petersburg przeistoczył się w cudowne dziecko oświecenia. W części ósmej badacz rozpatruje z kolei burzliwą działalność intelektualną jednej z ważniejszych instytucji władzy w imperium rosyjskim — Ministerstwa Spraw Wewnętrznych. W rozdziale dziewiątym nawiązuje do mało znanego epizodu z biografii Immanuela Kanta, kiedy to na kilka lat filozof został rosyjskim poddanym. Podług Etkinda nieprawdą jest, jakoby w ogóle nie interesowała go kwestia ucisku kolonialnego. Autor Krytyki czystego rozumu znalazł się wówczas w położeniu białego subalterna, co pozwala nazwać go (post)kolonialnym intelektualistą. Przedmiotem opisu w części dziesiątej są rosyjskie sekty religijne oraz ich mityczne i faktyczne powiązania z rewolucją. Misjonarze, historycy i etnografowie z końca XIX wieku, dokonujący egzotyzacji ludu rosyjskiego i opisujący jego „tajne życie”, mieli skłonność przypisywania mu wielu niesamowitych cech. W ten sposób udało im się przekonać narodników i socjalistów, że głoszone przez nich hasła rewolucyjne otrzymają natychmiastowe wsparcie ze strony ludowych sekt. W rozdziale jedenastym badacz dokonuje zestawienia antyimperialnych narracji Josepha Conrada i Nikołaja Leskowa. Obaj twórcy interesowali się przeszłością (onblm) imperium rosyjskiego, obaj też choć z różnych powodów - działania imperium poddawali krytyce. W ostatniej części, na przykładzie wybranych utworów literatury rosyjskiej - między innymi Córki kapitana Aleksandra Puszkina, Sobowtóra i Idioty Fiodora Dostojewskiego, Srebrnego gołębia Andrieja Biełego - Etkind porównuje powieść rosyjską z rytuałem ofiary (Meханизм жертвоприношения), decydującym o relacjach pomiędzy płciami i stanami w granicach imperium. Łączy on wypowiedzi teoretyczne Michaiła Bachtina i René Girarda $\mathrm{z}$ historycznym kontekstem kolonizacji wewnętrznej.

Trudne położenie, w jakim znalazł się główny bohater Gogolowskiego Nosa, stanowi zdaniem Etkinda egzemplifikację tego, co Homi Bhabha nazwał „rozdwojeniem kolonialnym" i potraktował jako nieunikniony aspekt świata społecznego ${ }^{6}$ imperialnej kolonii. Po powrocie z ogarniętego wojną Kaukazu (południowych rubieży imperium), asesor kolegialny Kowalow liczył na szybki awans i stanowisko

6 Terminem tym posłużył się w swych pracach Edmund Husserl (w oryginale Lebenswelt). Etkind tłumaczy go na rosyjski jako жизненный мир. 
zastępcy gubernatora w centralnej części Rosji, co pozwoliłoby mu wygodnie żyć na koszt miejscowej ludności. Realizację planów uniemożliwił mu jego własny nos, którego zniknięcie wywołało społeczne i zawodowe wykluczenie. Opisując „pozbawionego twarzy" kolonialnego administratora, Gogol zamienił jego nos w imperialny fetysz, „metonimię obecności”, nieosiągalnej i niepoznawalnej. Kowalow nie wyobraża sobie życia bez tej części ciała - to jest bez władzy, pieniędzy i kobiet. Będący na swoim właściwym miejscu nos - niewielka część całości - jest metonimią prostego (безупрёчного) funkcjonowania Kowalowa jako fizycznego i imperialnego podmiotu (телесной и имперский субъект). Jego nieobecność jest metaforą wszystkich niezrealizowanych marzeń i nieosiągniętych korzyści. W utworze Gogola relacja pomiędzy częścią a całością odpowiada opisanej przez Hegla relacji pomiędzy panem a niewolnikiem. Dopóki część podlega całości, nic nie zagraża ustanowionym porządkom. Bunt części przeciwko całości paradoksalnie okazuje się dużo groźniejszy niż bunt niewolnika przeciwko panu, narusza bowiem najgłębsze fundamenty porządku kulturowego, uznawanego błędnie za całkowicie naturalny.

Etkind nazywa Gogola - pisarza o klasycznej imperialnej biografii (dorastał na Ukrainie, skąd wyemigrował do Petersburga $)^{7}$ - wybitnym, porównywalnym z Jamesem Joyce’em i Josephem Conradem twórcą kolonialnym, który dokonał w Martwych duszach druzgocącej krytyki rosyjskich praktyk imperialnych. Główny bohater utworu, Cziczikow, planował przesiedlić nabytych chłopów z centralnej części Rosji do niedawno skolonizowanej guberni chersońskiej. W ocenie badacza powieść (podobnie jak wcześniejsza komedia Rewizor) jest klasycznym przykładem sagi kolonialnej w stylu Robinsona Crusoe czy Moby Dicka. Obojętnie, z nosem czy bez nosa, z martwymi duszami czy żywymi ludźmi, bohaterowie Gogola są typowymi „ludźmi postoświeceniowymi”, przywiązanymi do swego mrocznego cienia, któremu nie potrafią się przeciwstawić. Chodzi o przywiązanie do: „тени колонизованного им человека, которая расщепляет его существование, искажает его профиль, нарушает его границы, повторяет его действия на расстоянии, заполняет и разрушает само время его бытия"8. Chociaż badacze postkolonialni zwracali uwagę na pochodzenie Gogola oraz ukraińskie motywy jego twórczości ${ }^{9}$, to aspekt kolonialny tekstów, w których występują Rosja i Rosjanie (Nos, Martwe dusze) z reguły pomijali milczeniem. Aby go dostrzec i opisać niezbędna jest bowiem kategoria kolonizacji wewnętrznej.

W roku 1835 opublikowane zostało przemówienie lorda Thomasa Macaulaya Uwagi na temat edukacji w Indiach (Заметки об образовании в Индии), w którym brytyjski historyk i polityk przekonywał, że opanowanie języka angielskiego przez

7 Jak pisze Andrzej Andrusiewicz, Gogol jako artysta „sam siebie obarczył misją wskazywania sensu »ukraińsko-rosyjskiej jedności«". Ten jeden z najbardziej samorodnych, oryginalnych talentów literackich swego czasu pomysły czerpał z głębokiej znajomości rosyjskiego i ukraińskiego charakteru. Więcej zob. A. Andrusiewicz, Złoty sen. Rosja XIX-XX wieku. Sprawy i ludzie, Kraków 2016, s. 363.

${ }^{8}$ Etkind przywołuje w tym miejscu słowa Homiego Bhabhy. Zob. А. Эткинд, op. cit., s. 27.

${ }^{9}$ Gogol pełną garścią czerpał z folkloru ukraińskich obrzędów i legend. 
elity indyjskie pozwoli stworzyć „pośredników pomiędzy nami a milionami ludzi, podlegającymi naszej władzy”. Co ciekawe, za przykład godny naśladowania Macaulay uznał Rosję. Państwo to, twierdził, pod względem rozwoju cywilizacyjnego w czasach naszych dziadków było daleko w tyle za Pendżabem, ale już w czasach naszych wnuków doścignie Francję i Wielką Brytanię. W ujęciu Macaulaya metropolia i kolonie były kolejnymi szczeblami na tej samej drabinie postępu historycznego. Tam, gdzie Anglia była w wieku X, Rosja znalazła się w XVIII; wkrótce miał do niej dołączyć także Pendżab. Zdaniem Macaulaya w okresie rządów Piotra Wielkiego i jego następców języki państw zachodnich ucywilizowały Rosję - teraz podobny proces miał się dokonać w Indiach. Gdyby nie reformy Piotra I, pisał z kolei Wissarion Bielinski, to Rosja upodobniłaby się do Europy i przyjęła jej cywilizację na analogicznej zasadzie, jak Indie upodobniły się do Anglii. Bielinski postrzegał samowesternizację swojej ojczyzny jako udaną odpowiedź na kolonialne zakusy ze strony państw zachodnich. W rezultacie podczas gdy Indie nadal pozostawały państwem kolonialnym, Rosja dołączyła do grupy imperiów światowych. Różnica pomiędzy położeniem klas wyższych i niższych w imperium brytyjskim i rosyjskim była jednak ogromna. O ile w pierwszym przypadku decydujące znaczenie miał podział na metropolię i kolonie zamorskie, o tyle w drugim analogiczną funkcję pełniły różnice między stanami zamieszkującymi tę samą kontynentalną metropolię, posiadającą kolonie wewnętrzne. Na tego rodzaju nierównowagę rozwoju wskazywali marksiści - między innymi Lew Trocki. W Rosji żyły obok siebie społeczności progresywne i zacofane. Ich bezpośrednie sąsiedztwo oraz różnice interesów Etkind uznaje za jedną z ważniejszych przyczyn przyszłych rewolucji.

W apogeum rosyjskiego imperializmu (Высокий имперский период) - okresie, który zapoczątkowało zwycięstwo nad Napoleonem, a zakończyła porażka w wojnie krymskiej, wykształcone kręgi społeczeństwa pisały i mówiły po francuskim równie dobrze jak po rosyjsku. Obdarzona „duszą rosyjską" Tatiana, jedna z bohaterek Puszkinowskiego Eugeniusza Oniegina, nieprzypadkowo w listach do swego ukochanego (rosyjskiego szlachcica) używa języka Woltera, podobnie bowiem jak większość kobiet z jej kręgów rosyjski znała dużo gorzej. Przedstawiciele elity szlacheckiej korzystali z francuskiego w relacjach z kobietami oraz w życiu domowym, $\mathrm{z}$ rosyjskiego natomiast $\mathrm{w}$ dyskusjach na tematy wojenne lub dotyczące zarządzania majątkiem. Podobnie dzieje się w Wojnie i pokoju (1869) Lwa Tołstoja, gdzie oficerowie i urzędnicy z żonami i córkami rozmawiają po francusku, z podwładnymi po rosyjsku, z ludźmi zaś tej samej rangi w obu językach równolegle.

W roku 1836, po lekturze Demokracji w Ameryce Alexisa de Tocqueville’a, Piotr Czaadajew zainteresował się przeznaczeniem Rosji i wyalienowaniem tutejszych elit. Filozof doszedł wówczas do wniosku, że wraz z bogaceniem się i poszerzaniem granic imperium rosło wyobcowanie warstw uprzywilejowanych. Ich przedstawiciele (przede wszystkim mężczyźni) we własnych majątkach czuli się kolonialnymi zdobywcami, chociaż mieszkali w miastach. Byli koczownikami, w życiu zaś codziennym - obcokrajowcami. Na marginesie książki Etkinda warto zauważyć, że po- 
dobne zjawisko występowało także w siedemnasto- i osiemnastowiecznej Polsce. Jak pisze Jan Sowa w Fantomowym ciele króla, ówczesna szlachta uważała się za reprezentantów grupy nie tylko lepszej, lecz także istotowo odmiennej od reszty populacji. Zgodnie $\mathrm{z}$ sarmackim mitem grupa ta po migracji ze wschodu objęła panowanie nad Europą Środkowo-Wschodnią, podporządkowując swej władzy zamieszkującą te regiony ludność rolniczą ${ }^{10}$. Niepokój Czaadajewa budziło to, że w odróżnieniu od mieszkańców Ameryki Północnej Rosjanie nie mieli własnych „mędrców” i „myślicieli”. Zgodnie z propozycją Nancy Condee poczucie wyobcowania i powszechnego zastoju oraz niesamodzielności ojczystej kultury Etkind uznaje za przejaw orientalizmu wewnętrznego.

List filozoficzny Czaadajewa wywołał skandal, jego autor uznał bowiem Rosjan za ludzi mniej cywilizowanych od ,amerykańskich dzikusów”. Zdołał jednak zainspirować grupę intelektualistów-słowianofilów traktujących krytyczną ocenę kultury imperium jako szansę na odrodzenie narodu. To właśnie ich udziałem stało się powtórne odkrycie języka antyimperialnego protestu, którego korzenie tkwiły we francuskim oświeceniu, rewolucji amerykańskiej, krytyce działań Brytyjczyków w Indiach (Edmund Burke), okupacji państw niemieckich przez Napoleona oraz polskich powstaniach przeciwko carskiej Rosji.

W latach trzydziestych XIX wieku Gogol zwrócił uwagę na osobliwy wygląd Petersburga. Panująca w mieście atmosfera upodobniała je do europejskich kolonii w Ameryce. Częściej niż elementy krajobrazu spotykane w innych częściach Rosji występowały tu rozwiązania typowe dla Europy Północnej i Zachodniej. Ponieważ Gogol fascynował się wówczas Ameryką, uczynione przezeń porównanie nie miało pejoratywnego znaczenia. Zbliżone stanowisko zajmowali konserwatywni myśliciele $\mathrm{z}$ lat czterdziestych XIX wieku, którzy dokonując surowej oceny kultury rosyjskiej, stosowali wybitnie kolonialną terminologię. Jak twierdził na przykład Aleksiej Chomiakow, rosyjskie oświecenie od samego początku miało "charakter kolonialny”, rosyjskie warstwy wykształcone przypominały „kolonię europejskich eklektyków w kraju dzikusów". Zdaniem autora Jermaka w oświeconej Rosji panowały układy stricte kolonialne, których przejawem była jawna wrogość pomiędzy stanami społecznymi - lud nie ufał elitom, elity z kolei traktowały lud z ogromną pogardą. Według Chomiakowa o fatalnym stanie rosyjskiego społeczeństwa decydowały jego pęknięcie, niewolnicze naśladownictwo Zachodu oraz powszechny zastój umysłowy. Pęknięcie to zostało wywołane reformami Piotra I i utrwalone przez rządy jego następców. W sposób nieodwracalny oddzieliły one życie ludu od życia warstw uprzywilejowanych.

W roku 1832 ukazała się sztuka Chomiakowa poświęcona atamanowi Jermakowi, kozackiemu zdobywcy Syberii. Jermak został w niej ukazany nie jako bohater narodowy, lecz zwyczajny przestępca - wyklęty przez ojca, wtrącony do więzienia $z$ rozkazu cara, a następnie zdradzony przez własnych żołnierzy. Chociaż syberyjski

10 J. Sowa, Fantomowe ciało króla. Peryferyjne zmagania z nowoczesną formą, Kraków 2011, s. 38. 
szaman oferował mu koronę, ten zdecydował jednak popełnić samobójstwo. Jeżeli bohaterem podobnej tragedii byliby Krzysztof Kolumb lub Hernán Cortés, twierdzi Etkind, to badacze postkolonialni uznaliby ją za jeden z pierwszych tekstów o wymowie antyimperialnej. Chomiakow całe życie interesował się dziejami ludów kolonizowanych, między innymi Celtów, Hindusów i Hotentotów, a także zagadnieniami dotyczącymi funkcjonowania imperium, kolonii, migracji oraz podziałów w obrębie społeczeństwa rosyjskiego.

W tym samym czasie, kiedy administracja brytyjska przystąpiła do propagowania nauki języka angielskiego w Indiach, rosyjski minister oświaty Siergiej Uwarow doszedł do wniosku, że europeizacja Rosji zabrnęła zbyt daleko. Ten utalentowany administrator, w wolnych chwilach badacz kultury Wschodu, sprzyjał popularnym w ponapoleońskiej Europie ideom nacjonalistycznym (национальность), na podstawie których wypracował oryginalną kategorię ludowości (народность). Wskutek reform przeprowadzonych przez Macaulaya i Uwarowa nacjonalizm indyjski i rosyjski zaczęły nabierać całkowicie odmiennego charakteru. Pierwszy z nich stawał się coraz bardziej buntowniczy i antyimperialny, drugi zaś - oficjalny. Macaulay duże znaczenie przywiązywał do reform Piotra I, Mahatma Gandhi znacznie wyżej cenił z kolei nauki Lwa Tołstoja. W odróżnieniu od Anglii i Francji Rosja była mocarstwem europejskim, które nowe rozwiązania cywilizacyjne zapożyczało od państw zachodnich - analogicznie było w Indiach i Afryce. Z tego powodu Macaulay porównywał Rosję nie do imperium brytyjskiego, lecz jego azjatyckich posiadłości. Ostatecznie Rosja pełniła jednak funkcję zarówno imperium, jak i kolonii. Na początku lat sześćdziesiątych XIX wieku Fiodor Dostojewski zauważył, że nie ma na świecie drugiego równie niezrozumiałego kraju jak Rosja. Po powrocie z syberyjskiego zesłania autorowi Zbrodni i kary lud rosyjski wydał się niczym Sfinks całkowicie obcy, pełen zagadek, tajemnic i mądrości.

Dyskusje toczone w początkach XX stulecia wśród marksistów spowodowały, że część z nich zwróciła uwagę na zależność pomiędzy imperializmem a gospodarką narodową. Punktem wyjścia były prace Marksa, który, w ich przekonaniu, umiejętnie opisywał te skomplikowane relacje. Piotr Struwe zauważył wówczas, że skuteczną walkę klasową utrudnia postawa osób niezaliczających się ani do kapitalistów, ani do robotników (mpeтьи лиц a), których życie kształtowało się w warunkach typowych dla okresu protokapitalistycznego. Z kolei zdaniem Róży Luksemburg prowadzenie walki klasowej komplikowały przede wszystkim rynki zagraniczne. Kapitalizm nieustannie potrzebuje bowiem nowych rynków zbytu, co spaja go z imperializmem. Walka $\mathrm{z}$ kapitalizmem oznacza tym samym walkę przeciwko imperium. W książce zatytułowanej Rozwój kapitalizmu w Rosji Lenin przekonywał, że w rozległych państwach kontynentalnych, takich jak Rosja czy Stany Zjednoczone, nierównowaga rozwoju wewnętrznego staje się odpowiednikiem nierównowagi pomiędzy metropolią i jej koloniami. Wypracowane w metropolii „nadwyżki” służą kolonizacji wewnętrznej i sprzyjają rozwojowi kapitalizmu. W ten sposób nierówności wewnętrzne pełnią funkcję analogiczną do nierówności zewnętrznych. Opisując słabo rozwinięte 
terytoria nad Wołgą i na Syberii, Lenin często stosował pojęcia „kolonizacja wewnętrzna” i „,kolonia wewnętrzna”, odnoszone do obszarów zarówno z przewagą Rosjan etnicznych (Noworosja, okolice Archangielska), jak i ludności mieszanej (Krym, Syberia) oraz nierosyjskiej (Gruzja).

Z podobnej terminologii kolonialnej korzystał także amerykański historyk i czarnoskóry aktywista W.E.B. Du Bois - badacz dyskryminowanych mniejszości rasowych i społecznych w Stanach Zjednoczonych. Du Bois, tak samo jak Lenin, koncepcję kolonizacji wewnętrznej zaczerpnął z języka pruskiej biurokracji, w której interpretacji miała ona oznaczać państwowy program zagospodarowania terytoriów położonych pomiędzy Prusami a „dzikim” słowiańskim wschodem. To właśnie urzędnicy niemieccy planowaną politykę wschodnią określali jako „program kolonizacji wewnętrznej”, odróżniając ją od kolonizacji zewnętrznej Azji i Afryki. W późniejszych latach plany te zostały zarzucone i gruntownie skrytykowane między innymi przez Hitlera, wedle którego idea kolonizacji wewnętrznej była pomysłem z gruntu żydowskim.

W latach dwudziestych ubiegłego stulecia Antonio Gramsci opisał relację pomiędzy północną i południową częścią Włoch jako klasyczną eksploatację kolonialną. Jej wymiar kulturowy filozof nazwał hegemonią i całkowicie odróżnił od wymiaru politycznego (dominacji) i gospodarczego (eksploatacji). Chociaż pod względem ekonomicznym południowe Włochy były „eksploatowanymi koloniami” północy, cały czas znacząco oddziaływały na kulturę północnej części państwa. Gramsci przeszedł do historii jako twórca pojęć hegemonii i dominacji, bez których nie sposób wyobrazić sobie badania kulturowe i postkolonialne.

Analizując wzajemne relacje pomiędzy władzą (bliską hegemonii Gramsciego) a przemocą (bliską dominacji), Hannah Arendt zwróciła uwagę na tak zwany efekt bumerangu, występujący wówczas, gdy rządzący zaczynają przenosić kolonialne metody sprawowania władzy do metropolii. Według prognoz filozofki przemoc używana wobec „ras podporządkowanych” miała się zwrócić przeciwko samym Anglikom, którzy, w konsekwencji, staliby się „ostatnią rasą podporządkowaną”. Metafora bumerangu zasadza się na kantowskiej proweniencji, obawie o to, że Europejczycy będą rządzeni w przyszłości w taki sam sposób jak uznawane za „niezdolnych” do samodzielności, „niecywilizowane dzikusy”. Podobną opinię wyrażali antropolodzy, postrzegający kolonie na zasadzie „współczesnych laboratoriów”, w których wypróbowuje się nowe techniki władzy. Metafora bumerangu zajęła kluczową pozycję w Źródłach totalitaryzmu (1966) - jednej z ważniejszych prac Arendt — w której radziecki i faszystowski reżim totalitarny przyrównane zostały do praktyk towarzyszących europejskiej kolonizacji Azji i Afryki. Chociaż Etkind uznaje efektu bumerangu za koncepcję nad wyraz przydatną naukowo, to, jak podkreśla, aby odnosić ją do realiów rosyjskich, należy ujmować imperializm jako akt skierowany nie tylko na zewnątrz, ale także do wewnątrz państwa. Praktyki przymusu i przemocy, których imperium rosyjskie w ciągu wieków używało wobec własnych poddanych (przede wszystkim chłopów), pozwalają ukazać rewolucję październikową i będący jej na- 
stępstwem system totalitarny jako efekt bumerangu właśnie, uderzający z terenów podlegających niegdyś pańszczyźnie w miasta i instytucje państwowe. W ten oto sposób działania rosyjskiego bumerangu (российский бумеранг) doświadczyły obszary położone w centralnej części imperium. Etkind postrzega radziecki totalitaryzm jako całkowicie logiczną, choć skomplikowaną i typowo rosyjską realizację efektu bumerangu.

Zwracając uwagę na przenoszenie teorii rasowych z kolonii do Europy, Michel Foucault wskazywał na istnienie różnych odmian kolonializmu, które powodowały, że sam Zachód zaczynał podlegać kolonizacji wewnętrznej. Na długo przed Foucault rosyjski pisarz i satyryk Michaił Sałtykow-Szczedrin opublikował cykl szkiców Panowie taszkientczycy, w którym opisywał procesy analogiczne do efektu bumerangu i kolonizacji wewnętrznej. Taszkient, obecna stolica Uzbekistanu, po zdobyciu przez wojska rosyjskie w roku 1865 został wyznaczony na centrum rozległej środkowoazjatyckiej kolonii. Sukces rosyjskiego imperializmu umożliwił Szczedrinowi ukazanie jego antytetycznego wpływu (обратное действие) na politykę i obyczaje Rosji właściwej. Oficerowie i urzędnicy powracający do Moskwy i Petersburga z Azji Centralnej, Kaukazu oraz innych rosyjskich kolonii przywozili ze sobą zwyczaj stosowania różnego rodzaju praktyk przemocy. Chociaż, jak zauważa Etkind, typowy taszkientczyk „cywilizował” Polskę na długo przed rozpoczęciem służby w Azji Środkowej, to jednak dopiero tam odkry1, jak „ucywilizować” samą Rosję. Śledząc drogę powrotną imperialnego bumerangu z rosyjskich kolonii do metropolii, Sałtykow-Szczedrin scharakteryzował Wschód wewnętrzny — za pomocą jego własnego języka („taszkienctwo") - jako połączenie przemocy i ignorancji oddziałujące na relacje pomiędzy centrum Rosji a jej koloniami.

Zapoczątkowana w drugiej połowie XX wieku dekolonizacja państw Trzeciego Świata oraz desowietyzacja Świata Drugiego wielu krajom przyniosła wolność. Mimo iż historycznie oba zjawiska były z sobą ściśle powiązane, to narracja na ich temat pozostawała całkowicie odmienna. Od epoki oświecenia poczynając, także historia jako nauka miała własny efekt bumerangu — analizy procesów kolonizacji i dekolonizacji Wschodu pozwalały lepiej zrozumieć przemiany, którym podlegał sam Zachód. Jak twierdził brytyjsko-amerykański socjolog Michael Mann, w czasach współczesnych państwa postrzegane jako demokratyczne wymordowały w swych koloniach więcej ludzi niż autorytarne imperia. Powstawaniu liberalnych demokracji w metropoliach, a następnie w koloniach często towarzyszyły bowiem czystki etniczne, przybierające formę zinstytucjonalizowanej przemocy i prowadzące do masowych zbrodni. Dopóki imperia podtrzymywały istnienie skomplikowanej, pluralistycznej sieci władzy, dopóty udawało się uniknąć przelewu krwi na wielką skalę. Rozpad imperiów powodował, że budowane na ich gruzach państwa narodowe próbowały redukować swoje zróżnicowanie wewnętrzne poprzez rozwój procedur demokratycznych, upolitycznienie kultury, uniformizację edukacji, zmianę granic oraz transfery ludności. 
Skutkiem tych decyzji były nierzadko czystki etniczne, które Mann nazywa „ciemną stroną demokracji”, współczesnym „jądrem ciemności”"11.

Chociaż nacjonalizm rosyjski pojawił się w okresie wojen napoleońskich i trwał przez następnych dwieście lat, to imperium radzieckie zdołało skutecznie zamrozić jego rozwój. Rozpad ZSRR w roku 1991 piętnastu narodom, w tym także samym Rosjanom, przyniósł dekolonizację. Część badaczy, między innymi Geoffrey Hosking, słabość rosyjskiej demokracji oraz stosunkowo bezkrwawy upadek systemu radzieckiego tłumaczy właśnie nie do końca ukształtowanym rosyjskim nacjonalizmem. W pracy będącej rzadkim przypadkiem analizy przemian zachodzących na obszarze poradzieckim z wykorzystaniem narzędzi postkolonialnych David Chioni Moore wskazuje na zjawisko „podwójnego milczenia” — badacze postkolonialni nie wypowiadali się na temat przestrzeni poradzieckiej, sowietolodzy zaś i slawiści stronili od teorii postkolonialnej. W opinii Moore’a winę za taki stan rzeczy ponosiły marksistowskie sympatie badaczy postkolonialnych, które kazały im skutecznej alternatywy dla globalnego kapitalizmu upatrywać w gospodarce socjalistycznej. Z kolei uczeni z byłych państw socjalistycznych kultywowali swoją nową europejską tożsamość i unikali porównań własnych doświadczeń z doświadczeniami badaczy z Azji i Afryki. Rozbieżność między postkolonialnym i postsocjalistycznym stała się przyczyną, z jednej strony, depolityzacji badań postkolonialnych, z drugiej zaś prowincjonalizacji badań terytoriów poradzieckich. Jak zauważa Nancy Condee, milczenie lewicowych intelektualistów na temat Drugiego Świata oraz antykomunizm intelektualistów prawicowych były zjawiskami ściśle z sobą związanymi i wzajemnie się ograniczającymi. W opinii Etkinda nie tylko poradziecki okres historii Rosji ma wymiar postkolonialny ${ }^{12}$, już bowiem epoka radziecka miała w swej istocie podobny charakter.

Użyty przez Hannah Arendt i Edwarda Saida termin worldliness, Etkind tłumaczy na rosyjski jako жuть в миру ('żyć w świecie’) — za jego antonim uznaje zaś бeзмирность ('bycie poza światem'). Badacze historii powszechnej tradycyjnie wykazywali istnienie kilku światów - w okresie zimnowojennym wyróżniano trzy. Zgodnie $\mathrm{z}$ definicją Saida pojęcie orientalizmu dotyczyło praktyk postępowania Pierwszego Świata z Trzecim, zabrakło w niej jednak miejsca dla Drugiego. We wstępie do Orientalizmu amerykańsko-palestyński uczony uznał zimną wojnę - czas skrajnie burzliwych relacji pomiędzy Wschodem i Zachodem — za najważniejsze z historycznych wydarzeń, które umożliwiły studia nad orientalizmem. Teoria trzech światów została opracowana w połowie lat pięćdziesiątych ubiegłego stulecia w celu wyrażenia zaniepokojenia Zachodu wzrastającą popularnością ZSRR w byłych koloniach imperiów zachodnich, to jest obawą przed wpływem Drugiego Świata na Trzeci. Zasługą Saida była integracja Wschodu tradycyjnego (Orientu) ze Wschodem nietradycyjnym (Rosją) w obdarzony całkowicie nowym znaczeniem Wschód rozumiany jako

11 А. Эткинд, op. cit., s. 42.

12 Zdaniem Etkinda Rosja nadal jest imperium, znacznie jednak okrojonym. 
East. Mimo to w kolejnych rozdziałach swej książki badacz skupił uwagę wyłącznie na relacjach Zachodu ze „Wschodem tradycyjnym”. Zdaniem Saida fałszywy obraz mieszkańców Wschodu ukształtowany został na podstawie negatywnych stereotypów orientalistycznej proweniencji. Tego nie sposób przecenić. Wiedza na temat ludności zamieszkującej kolonie bezpośrednio oddziaływała na światopogląd kolonizatorów i stosowane przez nich praktyki władzy. $Z$ tego powodu wielkie teksty „kultury Zachodu” nigdy nie były niewinne, nieustannie czerpały bowiem z doświadczeń kolonialnych i imperialnych. Said zapoczątkował krytykę tradycyjnego orientalizmu, traktującego Zachód i Wschód jako samowystarczalne platonowskie jednie, rozszczepiające świadomość imperialną (имперское воображение) i zamieniające ją $\mathrm{w}$ „manichejskie złudzenie”.

Ustalenia Saida zostały uzupełnione przez jego uczniów i następców. Jak wykazał badacz dziejów imperium brytyjskiego David Cannadine, wymiana kulturowa pomiędzy metropolią i koloniami odbywała się w obu kierunkach jednocześnie. „Orientalizm” Brytyjczyków, zafascynowanych indyjską kuchnią, modą i religią, nie był tu wyjątkiem. W swoich koloniach Anglicy starali się zauważać głównie to, co przypominało im ojczyznę, zjawiska zaś składające się na egzotyczny i wrogi chaos były przez nich konsekwentnie ignorowane. Podejście to umożliwiło im pozostawanie w obrębie dobrze znanych hierarchii. Dostrzeżenie pozytywnych aspektów kolonializmu pozwoliło Homiemu Bhabhie na dokonanie korekt w wypracowanym przez Saida podziale na imperialnych władców i kolonialnych poddanych. Dzięki jego pracom zjawisko hybrydyzacji kulturowej stało się jednym z bardziej eksploatowanych zagadnień w ramach teorii postkolonialnej. O ile Frantz Fanon i Edward Said kładli nacisk na „manichejską odmienność” kolonizatorów i kolonizowanych, o tyle uwagę przedstawicieli nowej fali postkolonializmu zwróciły „szare strefy”, to, co „usytuowane pomiędzy” (срединные образования).

W odróżnieniu od innych europejskich mocarstw imperium rosyjskie położone było pomiędzy Wschodem i Zachodem. Zdaniem Etkinda jego skomplikowana struktura wewnętrzna, składająca się z elementów wschodnich i zachodnich, jak również wyróżniająca Rosjan skłonność do samorefleksji, pozwalały w sposób twórczy łączyć orientalizm z okcydentalizmem. Konstrukcja ta w niczym nie przypominała Zachodu i Wschodu funkcjonujących na zasadzie wzajemnie wykluczających się jedni. W granicach państwa rosyjskiego Wschód i Zachód były z sobą splecione niczym heraklitejskie żywioły.

W dalszej części swej książki Etkind próbuje udowodnić, że analizowane przez Saida teksty Defoe, Kiplinga i Balfoura, w których pojawia się Rosja celowo konstruowano tak, aby snuta w nich opowieść była jednocześnie orientalistyczna i „nietradycyjna", całkowicie różna od tego, co Said nazywał normatywnym zachodnim tekstem na temat „Wschodu tradycyjnego”. Jednym z utworów kształtujących poglądy Saida były Przypadki Robinsona Crusoe. Autora Orientalizmu najbardziej interesował stosunek tytułowego bohatera do pieniędzy, podróży i samotności. W opinii Etkinda Said nadmiernie skupił się jednak na pierwszej części trylogii, całkowicie pomija- 
jąc część drugą - Dalsze przypadki Robinsona Crusoe, w której podróżnik dociera do Madagaskaru, Chin, Tartarii oraz Syberii. Doświadczane przezeń przygody są zupełnie innego rodzaju niż w tomie pierwszym. Przemierzając Syberię szlakiem z południa na zachód, Robinson czuje spore rozczarowanie. Wcześniej zakładał bowiem, że obszary położone bliżej Europy będą bardziej kulturalne i gęściej zaludnione. Tymczasem na podlegających władzy Rosji ziemiach Tunguzów spotyka pogan i barbarzyńców. Robinson z zaciekawieniem przygląda się wzniesionym z rozkazu cara miastom i osadom oraz posterunkom wojskowym, które przypominają mu garnizony strzegące granic imperium rzymskiego. Korzystając z okazji, przekazuje „moskiewskim zarządcom” Syberii swoje uwagi na temat barbarzyństwa tutejszej ludności, w odpowiedzi słyszy jednak, że niewiele ich one obchodzą. Ich zdaniem gdyby car pragnął uczynić z tutejszych mieszkańców chrześcijan, to przysłałby nie wojsko, lecz misjonarzy. Z punktu widzenia interesów carskich ważniejsze jest, aby ludzie ci stali się jego poddanymi, a nie chrześcijanami. Podróżnik dowiaduje się także, że Syberia służy jako miejsce zsyłki różnego rodzaju przestępców. Wśród nich znajduje się rosyjski książę, któremu Robinson oferuje pomoc w ucieczce do Anglii. Propozycja zostaje jednak odrzucona. Wedle księcia na zesłaniu udało mu się odnaleźć szczęście i spokój, nie chce więc kupować pozoru wolności (freedom) za cenę wolności własnego rozumu (liberty). Na pamiątkę spotkania Anglik otrzymuje od Rosjanina sobole futro. Zdaniem Etkinda ten fragment Dalszych przypadków... ma skomplikowaną wymowę moralną. Opis typowych dla syberyjskiej ludności praktyk pogańskich pozostaje w ścisłym związku ze światopoglądem Robinsona - podróżnika-purytanina dokonującego nieustannej egzotyzacji Wschodu. Jego krytyka skupia się na obojętnym stosunku cara do chrystianizacji miejscowej ludności, co odzwierciedla poglądy samego Defoe na temat brzemienia imperium. Podarowany przez księcia cenny prezent, jak również cechy charakteru rosyjskiego wielmoży powodują, że czytelnik postrzega go jako bogatszego, mądrzejszego i szlachetniejszego od brytyjskiego handlowca. Książę, będący w stanie nienaganną angielszczyzną wytłumaczyć różnicę pomiędzy wolnością osobistą (freedom) i wolnością wewnętrzną (liberty), jawi się jako człowiek oświecenia, co korzystnie odróżnia go od Robinsona. Szlachetny książę ujawnia tym samym oryginalną cechę rosyjskiego kolonializmu, nieoczekiwaną dla ludzi Zachodu, w którym to, co wysokie, i to, co niskie, przybiera skrajne rozmiary.

„О, Запад есть Запад, Восток есть Восток, и с мест они не сойдут"13 stwierdził w roku 1889 Rudyard Kipling. Tak naprawdę jednak Zachód i Wschód spotykały się wielokrotnie, o czym - według Etkinda - autor Kima musiał dobrze wiedzieć. Analizując relacje pomiędzy Pierwszym i Trzecim Światem, badacze postkolonialni zbyt dosłownie traktowali początkowe słowa ballady Kiplinga, pomijając ich wymiar dekonstrukcyjny. W Wielkiej Grze pomiędzy imperium rosyjskim i brytyjskim, tworzącej tło zdarzeń opisanych w Kimie, tak naprawdę udział bierze

13 А. Эткинд, op. cit., s. 53. 
nie dwóch, lecz trzech graczy - Anglia, Indie oraz będąca w cieniu złowroga Rosja. Podporządkowane wymogom geopolityki zasady gry powodują, że Indie zwracają się na Zachód, Rosja zaś na Wschód. Z tego powodu Kim, irlandzki emigrant, który w Azji został brytyjskim szpiegiem, usiłuje za wszelką cenę powstrzymać rosyjską ekspansję.

W wierszu Kiplinga zatytułowanym Мировая с Медведем (Truce of the Bear) zwraca uwagę postać kalekiego żebraka, Matuna, opowiadającego brytyjskim żołnierzom o nierównej walce, jaką stoczył z przerażającym stworzeniem — „Niedźwiedziem, który porusza się jak człowiek”. Spotkawszy to zwierzę przed pięćdziesięcioma laty, kierując się litością, myśliwy zaniechał strzału, wskutek czego niedźwiedź rozorał mu twarz. Obecnie Matun ostrzega Brytyjczyków, aby nie zawierali traktatu pokojowego ze zwierzęciem przypominającym człowieka. Chociaż w utworze Kiplinga o Rosji nie mówi się wprost, to kolejne pokolenia czytelników uznawały niedźwiedzia za symbol Rosji. Wiersz był ostrzeżeniem przed wchodzeniem w układy z niebezpiecznym przeciwnikiem. Po rewolucji październikowej rusofobiczne nastroje w Wielkiej Brytanii nie były jednak zbyt popularne. Zdaniem Etkinda interpretacja Saida pomija istotny aspektu utworu. Rzecz w tym, że pozbawiony zębów, warg, nosa i oczu żebrak mało przypomina człowieka, Niedźwiedź natomiast - straszny, kosmaty - i owszem. Człowiek i Niedźwiedź potraktowani zostali niczym bliźnięta toczące odwieczne zmagania, których rezultat rozstrzygnie przyszłość. Znaczenie ma również to, że Matun nie jest białym człowiekiem, lecz indyjskim krajowcem. Analogicznie jak w Kimie w zdarzeniach uczestniczy trzech bohaterów - starcie i układ są dziełem indyjskiego myśliwego i rosyjskiego niedźwiedzia, Anglicy zaś z zainteresowaniem i niepokojem wysłuchują tej niesamowitej opowieści.

W schyłkowym okresie epoki imperialnej Wielka Brytania coraz częściej postrzegała Rosję jako swego najgroźniejszego przeciwnika. Za życia Kiplinga w obu państwach rozpatrywano możliwość rosyjskiego ataku na Indie, który miał być zemstą za porażkę w wojnie krymskiej i doprowadzić do wyparcia Anglików z Azji. Termin „Wielka Gra” pojawił się w roku 1840 na oznaczenie angielskiej misji cywilizacyjnej w Azji Środkowej. Wzrost rosyjskich wpływów w tej części świata spowodował jednak, że jego znaczenie się zmieniło. Wielką Grą zaczęto nazywać lokalny konflikt pomiędzy dwoma wrogimi imperiami. Pod koniec lat siedemdziesiątych XIX wieku A. Dekhnewallah opublikował pamflet zatytułowany Великое российское вторжение в Индию (1879), w którym opisał przyszłą wojnę pomiędzy Rosją i Wielką Brytanią. Podbój Indii miała ułatwić działalność rosyjskich szpiegów, podburzających niższe kasty do buntu. Mimo to, przewidywał Dekhnewallah, Brytyjczycy zdołają odeprzeć siły wroga i przenieść działania wojenne na terytorium Kaszmiru. Obecność brytyjskiej floty na Morzu Czarnym i Bałtyckim zmusi Rosję do zawarcia niekorzystnego traktatu pokojowego, w którego wyniku utraci ona wpływy w Persji i Afganistanie.

Podobny wydźwięk miało opowiadanie Kiplinga Быщвый (The man who was). Kipling przekonywał w nim, że każdy „Rosjanin pozostaje uroczym człowiekiem, 
dopóki nie założy koszuli”, czyli nie zaczyna naśladować Anglików. Zdarzenia opisane w utworze Etkind traktuje jako nader symptomatyczne. W brytyjskim pułku w Indiach Północnych zjawia się niejaki Dyrkowicz, który choć podaje się za kozackiego oficera i dziennikarza, w rzeczywistości okazuje się rosyjskim szpiegiem. Nie przeszkadza mu to jednak zyskać szacunek brytyjskich oficerów; przekonuje żołnierzy o spoczywającej na nich misji cywilizacyjnej, wymagającej wspólnego wysiłku Rosji i Wielkiej Brytanii. Chociaż Brytyjczycy nie ufają przybyszowi, to traktują go jak człowieka tej samej rasy. Całkowicie odmienny jest ich stosunek do indyjskiego oficera - skądinąd wiernego towarzysza walk $-\mathrm{z}$ którym nigdy nie siadają przy jednym stole. Podczas rozmowy w wojskowej kantynie pojawia się dziwna, nieprzypominająca człowieka istota - mówiący po rosyjsku i angielsku, nędznie wyglądający Afgańczyk. Jak się okazuje, jest to były oficer pułku walczącego na Krymie, który najpierw został wzięty do niewoli, a następnie zesłany na Syberię. Dyrkowicz grozi brytyjskim oficerom, że w przyszłości mogą podzielić jego los, z tą różnicą, że nie zdołają się uwolnić i powrócić do swoich. Po odjeździe rosyjskiego szpiega jeden z żołnierzy zauważa z niepokojem: „Вот уж будет веселье, когда он вернется вновь" ${ }^{14}$. Według Etkinda motyw powrotu ma w utworze kluczowe znaczenie. Stacjonujący w Indiach żołnierze brytyjscy oczekują odwetu ze strony Rosjan za straty poniesione w wojnie krymskiej. W tym miejscu Kipling podkreśla raz jeszcze, że każdy Rosjanin może być czarujący wyłącznie jako człowiek Wschodu. Jego anomalia rasowa ujawnia się w chwili, gdy żąda, aby uznać go za najbardziej wschodniego spośród ludzi Zachodu, a nie jak widzą to Anglicy - najbardziej zachodniego reprezentanta Wschodu.

Współczesny Kiplingowi lord George Curzon odwiedził Rosję jeszcze przed objęciem urzędu wicekróla Indii. Jego zdaniem żadna inna kwestia nie wywoływała w Anglii takich sporów, jak rosyjskie plany odnośnie do Indii, na co zwrócił uwagę już w pierwszej z swych książek. Zauważył też, że niemal każdy Anglik przybywający do Rosji był rusofobem, w trakcie pobytu stawał się jednak rusofilem. Nie znaczy to, że po wyjeździe Curzon przestał dostrzegać zagrożenie ze strony Rosjan. Wręcz przeciwnie, stale przekonywał, że: „Rosja musi kroczyć naprzód, podobnie jak Ziemia musi kręcić się wokół Słońca”. Na rewolucję październikową Kipling zareagował wierszem Россия - пацифистам, w którym opłakiwał upadek imperium rosyjskiego i wyrażał zaniepokojenie możliwością powtórzenia się tego rodzaju zdarzeń w swojej ojczyźnie. Dla Etkinda utwór ten jest jednym z wcześniejszych przejawów zaniepokojenia efektem bumerangu.

Saidowska definicja orientalizmu dotyczy systemu fikcji ideologicznych i praktyk kulturowych, negatywnie oddziałujących na życie mieszkańców Wschodu oraz na panujące w państwach zachodnich wyobrażenia na ich temat. Skutkiem aktywności politycznej jest wiedza kształtująca zachowania kolonizatorów i określająca ich perspektywy badawcze. Jako przykład może posłużyć działalność Arthura Bal-

14 Ibidem, s. 57. 
foura, angielskiego polityka z początków XX wieku, który w roku 1917 umożliwił migrację ludności pochodzenia żydowskiego do Palestyny. Zdaniem Saida, forsując to rozwiązanie, Balfour postępował wedle zasady, zgodnie z którą człowiek Zachodu całkowicie różni się od człowieka Wschodu. Podczas gdy przeznaczeniem tego pierwszego jest sprawowanie rządów, drugi winien podlegać jego władzy. Według Saida przekonanie o krańcowej odmienności Wschodu i Zachodu umożliwiło „precyzyjne i efektywne" (буквальное и эфффективное) zastosowanie Balfourowskiej wersji orientalizmu. Balfour wychodził z założenia, że wraz z upływem czasu przepaść pomiędzy mieszkańcami Wschodu i Zachodu będzie się powiększać - pierwsi staną się jeszcze bardziej „wschodni”, drudzy zaś jeszcze bardziej „zachodni”. Proces ten amerykańsko-palestyński badacz określił jako „polaryzację różnicy”. Ludzie Wschodu z punktu widzenia Balfoura byli niczym platońskie jednie.

W roku 1917 Balfour posłużył się cytatem z utworu Kiplinga — „Zachód zawsze będzie Zachodem, a Wschód Wschodem" - w celu przekonania swoich kolegów z gabinetu ministrów, że takie terytoria jak Indie nigdy nie powinny otrzymać samorządności. Nawet na Zachodzie, utrzymywał, instytucje parlamentarne sprawdzają się wyłącznie w państwach anglojęzycznych. W odpowiedzi na wydarzenia w porewolucyjnej Rosji orientalistycznej proweniencji poglądy Balfoura dotyczyły już nie tylko Hindusów czy Arabów, ale także rosyjskich Żydów. Kilka lat przed wybuchem pierwszej wojny światowej polityk zapytał przywódcę syjonistów, Chaima Weizmanna (emigranta z dzisiejszej Białorusi): gdzie ludność żydowska chciałaby się osiedlić - w Palestynie, w Ugandzie, a może w granicach rosyjskiej strefy osiedlenia? Z punktu widzenia Balfoura pochodzący spod Pińska Weizmann musiał wyglądać nader egzotycznie. Dziesięć lat później, już jako minister spraw zagranicznych, Balfour wręczył Weizmannowi słynną deklarację zawierającą brytyjskie poparcie dla utworzenia w Palestynie „żydowskiej siedziby narodowej”. Ratyfikacja tego dokumentu nie oznaczała jednak automatycznego powstania państwa żydowskiego. Na podobnej zasadzie rosyjska strefa osiedlenia także nie była odrębnym państwem. Co ciekawe, deklarację Belfoura podpisano 2 listopada 1917 roku, dokładnie pięć dni przed przewrotem bolszewickim. Większość polityków brytyjskich uznawała Wschód za obszar wyjątkowo zróżnicowany etnicznie, zamieszkany przez liczne, skonfliktowane z sobą narody. Rola rozjemcy, jakiej podjął się rząd Balfoura, miała sprzyjać interesom imperium. W oczach Brytyjczyków Wschód tworzył coś na wzór wittgensteinowskiej konstelacji obrazów, ludzi i terytoriów, których nie łączyło nic poza przepaścią dzielącą ich od Trinity College w Cambridge, gdzie Balfour studiował prawo.

W odróżnieniu od Kiplinga, dla którego Rosja pozostawała mitycznym wrogiem, Joseph Conrad na własnej skórze doznał charakteru rosyjskich rządów w Polsce. To spowodowało, że kolonizację rosyjską pisarz przez całe życie postrzegał jako totalną katastrofę. Mimo to w książce Joseph Conrad i fikcja autobiograficzna doświadczenia pisarza z imperium rosyjskim Said pominął milczeniem. Strategię tę Etkind uznaje za błędną, nie sposób bowiem właściwie ocenić twórczości autora 
Jądra ciemności bez uwzględnienia jego stosunku do Rosji. Dokonując krytycznej analizy poglądów oraz tekstów Balfoura, Curzona, Kiplinga i Conrada, amerykańsko-palestyński badacz pomijał Rosję, redukując tym samym ich wielowymiarową przestrzeń do tradycyjnego, uproszczonego orientalizmu. Podejście to Etkind tłumaczy światopoglądem Saida, w którym Drugi Świat zajmował miejsce dość marginalne. Przełomowym wydarzeniem w biografii badacza, dorastającego w rodzinie bogatych arabskich chrześcijan w Jerozolimie i Kairze, była rewolucja egipska (1952), w której wyniku jego ojciec ucierpiał finansowo, matka zaś opowiedziała się po stronie Gamala Nasera, coraz wyraźniej sympatyzującego ze Związkiem Radzieckim. Siedemnastoletni wówczas Said był świadkiem i uczestnikiem sporów rodzinnych na tematy polityczne. Jak się okazało, zdecydowanie bliższe były mu poglądy matki, chociaż raził go jej „socjalistyczny panarabizm”. Oponentem politycznym Saida stał się w tym czasie jego wuj, Charles Malik - libański filozof, polityk i dyplomata, którego przyszły uczony oceniał jako człowieka charyzmatycznego i kontrowersyjnego, prawdziwego rycerza zimnej wojny. Głównym tematem jego wystąpień był antykomunizm. $Z$ upływem lat Said nabierał coraz większego dystansu do poglądów Malika, nieustannie ostrzegającego „wolny świat” przed groźbą zniewolenia przez imperium radzieckie. Malik gardził neutralnością, a w swych tekstach filozoficznych często używał pojęć „Wschód” i „Zachód”. Chociaż libański chrześcijanin atakował zarówno komunizm, jak i islam, to do ZSRR żywił szczególną antypatię. W roku 1953 przestrzegał, że komuniści mają nieskończenie bogaty arsenał sposobów, za pomocą których mogą wpływać na stosunki pomiędzy Wschodem i Zachodem. Wedle Saida była to najważniejsza negatywna lekcja w jego życiu.

Dla intelektualistów wywodzących się z państw Trzeciego Świata ZSRR stanowił natchnienie i wzór do naśladowania. Myśliciele o poglądach skrajnie lewicowych nieustannie udzielali wsparcia ruchom wyzwoleńczym, którymi kierowali, a niekiedy wręcz manipulowali przywódcy radzieccy. Zdaniem Etkinda o konwergencji nastrojów antyimperialnych i idei komunistycznych świadczy działalność Johna Reeda, Róży Luksemburg, Antonia Gramsciego czy Jean-Paula Sartre’a. Po pewnym czasie liberalni intelektualiści o poglądach marksistowskich pozbyli się jednak wszelkich złudzeń. Mimo to narracje używane przez dwudziestowiecznych myślicieli w celu opisania dwóch najważniejszych zjawisk tamtych czasów - dekolonizacji i upadku imperiów z jednej strony, $z$ drugiej zaś zimnej wojny i rozpadu systemu socjalistycznego - wyraźnie ze sobą kolidowały.

Prace Saida ujawniają istotną wadę teorii postkolonialnej, pomijającej milczeniem Drugi Świat, uznawany za niepotrzebną przeszkodę. Z punktu widzenia liberalnych zwolenników teorii modernizacji Drugi Świat niczym w zasadzie nie różnił się od Trzeciego - oba postrzegane były jako kolejne szczeble na tej samej drabinie postępu wiodącej ku Pierwszemu ze światów. Z kolei dla badaczy postkolonialnych Drugi Świat niewiele odbiegał od Pierwszego - żaden z nich nie potrafił bowiem skutecznie pomóc Trzeciemu. Obojętność wobec Drugiego Świata wzmocnił rozpad imperium radzieckiego. Niemniej, zauważa Etkind, Said nigdy nie należał do 
sympatyków ZSRR i wyraźnie dystansował się od proradzieckich idei głoszonych w jego ojczyźnie, szukając drogi pośredniej między Naserem a Malikiem. Po rozpadzie systemu socjalistycznego autor Kultury i imperializmu unikał wypowiedzi na temat Drugiego Świata, gdyż musiałby przyznać słuszność przewidywaniom swego wuja. W jednej z ostatnich książek (Фрейд и неевропейское, 2003) postanowił jednak przyjrzeć się bliżej Europie Wschodniej. Jego uwagę zwróciła znana i kontrowersyjna teza Freuda, zgodnie z którą twórca judaizmu, Mojżesz, nie był Żydem, lecz Egipcjaninem. W przekonaniu Etkinda Said miał absolutną rację, wskazując na pełen orientalistycznych clichés stosunek Freuda do Egiptu. Na podobnej zasadzie austriacki psychiatra postrzegał także „Wschód nietradycyjny”, czyli Rosję. Ludzie ze środowiska Freuda (niemieccy i austriaccy Żydzi) spoglądali na żydowskich uchodźców z Europy Wschodniej przez pryzmat stereotypów opisanych przez Saida w Orientalizmie.

Chociaż przywołane w artykule ustalenia Etkinda na temat koncepcji kolonizacji wewnętrznej nie obejmują całości ksiązki, to pozwalają, jak sądzę, wyrobić sobie orientację na temat poruszanych w niej zagadnień. Ograniczyłem się do zrelacjonowania problematyki podnoszonej we Wstępie oraz dwóch pierwszych częściach (rozdziały Два, но меньше чем один oraz Жить в миру), będących punktem wyjścia dalszych rozważań (części Писать с начала, Коммунальная империя, Бремя бритого человека). Ich problematykę, zasygnalizowaną na stronach szóstej i siódmej, zamierzam omówić w kolejnych publikacjach.

\section{Bibliografia}

Andrusiewicz, Andrzej. 2016. Złoty sen. Rosja XIX-XX wieku. Sprawy i ludzie. Kraków: Wydawnictwo Literackie.

Sowa, Jan. 2011. Fantomowe ciało króla. Peryferyjne zmagania z nowoczesną formą. Kraków: Universitas.

Россия как колония. Стенограмма обсуждения книги: А. Эткинд, Д. Уффельманн, И. Кукулин, Там, внутри. Практики внутренней колонизации в культурной истории России, https:// polit.ru/article/2013/01/03/colonization/ (dostęp: 2.11.2018).

Уффельманн, Дирк. 2012. „Подводные камни внутренней (де)колонизации России”. W: Там, внутри. Практики внутренней колонизации в культурной истории России, 53-104. Москва: Новое Литературное Обозрение.

Эткинд, Александр. 2013. Внутренняя колонизация. Москва: Новое Литературное Обозрение.

Эткинд, Александр, Дирк Уффельманн, Илья Кукулин. 2012. Там, внутри. Практики внутренней колонизации в культурной истории России. Москва: Новое Литературное Обозрение.

Przyjęto do druku/Accepted for publication: 30.04 .2020

Miscellanea Posttotalitariana Wratislaviensia 8, 2020

(C) for this edition by CNS 